\title{
Analysis of anti-corrosion coating process on steel constructions
}

Borkowski Stanisław, Stasiak-Betlejewska Renata

Institute of Production Engineering, Czestochowa University of Technology, Czestochowa University of Technology, Al.

Armii Krajowej 19B. 42200 Częstochowa. POLAND. e-mail: bork@zim.pcz.pl, renatastasiak@wp.pl

Nonconformities identified in anti-corrosion coating process on the steel constructions were analyzed in the article. Analysis of these nonconformities allows for process improvement by finding new ways of process leading.

Keywords: quality, anti-corrosion coating process, nonconformities

\section{References}

[1] BORKOWSKI S., Mierzenie poziomu jakości, Wydawnictwo Wyższej Szkoły Zarządzania i Marketingu, Sosnowiec 2004, ISBN 83-89275-26-0.

[2] JAGUSIAK M., CZAJA P., MASZKE A. 2009. Costs of non-conforming products in metalworks. Chapter 2. In: Toyotarity. Strategic areas- elements of Toyota house's roof. Borkowski S., Chuan T.K. (ed.). Publisher Yurii V. Makovetsky. Dnipropetrovsk.

[3] NÁPRSTKOVÁ N., Možnosti počítačové podpory metod obrábění ve strojírenské výrobě [in:] Bulletin vědecký, výzkumných a pedagogických prací ústavu za rok 2001, Ústí nad Labem UJEP, 2002.

[4] KVAPIL T., POHORALÝ M., Total Quality Management (TQM). In Strojirenská technologie X, 06/2005, No2. pp. 25-29. ISSN 1211-4162.

Reviews:

Prof. Iva Nová, MSc., PhD.

Assoc. Prof. Dana Bolibruchová, MSc., PhD. 